\title{
Collagen type I and decorin expression in tenocytes depend on the cell isolation method
}

\author{
Markus U Wagenhäuser ${ }^{1 \dagger}$, Matthias F Pietschmann ${ }^{1 *}$, Birte Sievers ${ }^{1}$, Denitsa Docheva ${ }^{2}$, Matthias Schieker ${ }^{2}$, \\ Volkmar Jansson ${ }^{1}$ and Peter E Müller ${ }^{1}$
}

\begin{abstract}
Backround: The treatment of rotator cuff tears is still challenging. Tendon tissue engineering (TTE) might be an alternative in future. Tenocytes seem to be the most suitable cell type as they are easy to obtain and no differentiation in vitro is necessary. The aim of this study was to examine, if the long head of the biceps tendon (LHB) can deliver viable tenocytes for TTE. In this context, different isolation methods, such as enzymatic digestion (ED) and cell migration (CM), are investigated on differences in gene expression and cell morphology.

Methods: Samples of the LHB were obtained from patients, who underwent surgery for primary shoulder arthroplasty. Using ED as isolation method, $0.2 \%$ collagenase I solution was used. Using CM as isolation method, small pieces of minced tendon were put into petri-dishes. After cell cultivation, RT-PCR was performed for collagen type I, collagen type III, decorin, tenascin-C, fibronectin, Scleraxis, tenomodulin, osteopontin and agreccan.

Results: The total number of isolated cells, in relation to $1 \mathrm{~g}$ of native tissue, was 14 times higher using ED. The time interval for cell isolation was about 17 hours using ED and approximately 50 days using CM. Cell morphology in vitro was similar for both isolation techniques. Higher expression of collagen type I could be observed in tenocyte-like cell cultures (TLCC) using ED as isolation method $(p<0.05)$, however decorin expression was higher in TLCC using CM as isolation method $(p<0.05)$. Dedifferentiation potential seemed to be similar for both isolation techniques.

Conclusion: In summary tenocyte-like cells can be obtained with both isolation methods (ED and CM) from the LHB. As no obvious disadvantage could be seen using ED, this method is more suitable for clinical use, as time for cell isolation is shorter and a remarkably higher number of cells can be obtained. However, both isolation methods can further be improved.
\end{abstract}

Keywords: Tenocytes, Tissue engineering, Isolation method, Gene expression

\section{Backround}

Tendon and ligament injuries are common injuries in Orthopedics. The most important injuries are ruptures of the anterior cruciate ligament in the knee, rotator cuff tears in the shoulder and ruptures of the Achilles tendon [1].

Up to date, the treatment of severe rotator cuff tears remains challenging. The dimension of these ruptures often does not allow a complete reconstruction. Only specific groups of patients benefit from tendon transfer

\footnotetext{
* Correspondence: Matthias.Pietschmann@med.uni-muenchen.de ${ }^{\dagger}$ Equal contributors

'Department of Orthopaedic Surgery, Ludwig-Maximilians-University Munich Campus Grosshadern, Marchioninistr 15, 81377, Munich, Germany
} Full list of author information is available at the end of the article procedures. In Europe, allogenic tendons grafts are not used routinely [2]. Moreover, in 2006 Moore et al. advised not to use allogenic tendon grafts for rotator cuff reconstruction, because the clinical outcome was comparable to simple debridement and had an increased risk of infection and host-versus-graft-reaction [3].

In future, an alternative approach for irreparable rotator cuff tears might be tendon tissue engineering (TTE). It tries to create tendon tissue of good quality in vitro aiming to take over its specific function in situ after implantation. An important issue for the TTE is to find out which cell type is the most effective for in vitro cell seeding. The ideal cell type should fulfill certain criteria. Firstly, it should be possible to isolate cells from

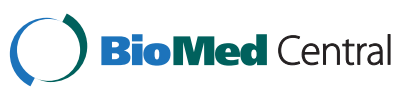


autologous tissue to avoid host-versus-graft reaction after implantation. Secondly, an adequate number of vital cells should be available after the cell isolation. Thirdly, these cells should have the ability to expand in vitro as well as to maintain phenotypic stability throughout the passages [4].

So far, fibroblasts, mesenchymal stem cells and tenocytes have been investigated [5-7]. Tenocytes might be the most suitable cells as no differentiation during in vitro cultivation is necessary. Tenocytes have been shown to grow in vitro without signs of senescence [8]. There is also evidence that cell proliferation of tenocytes in vitro is comparable to mesenchymal stem cells [9].

In this context, the long head of the biceps tendon (LHB) seems to be promising for tenocyte isolation. A (partial or complete) rupture of the LHB is often found in association with rotator cuff tears [10,11]. For this reason tenotomy of the LHB is performed regularly during rotator cuff reconstruction [12-14]. Donor side morbidity after tenotomy of the LHB is negligible and patient satisfaction is high [15].

There are two different methods to isolate tenocytes from tendon tissue. Tenocytes can be isolated using enzymatic digestion (ED) of the extracellular matrix compounds $[6,16]$. Another alternative is to obtained tenocytes by cell migration (CM) as cells migrate out of the tissue explants after culturing in cell culture medium [17].

Tenocytes synthesize specific proteins of the extracellular matrix, which has a highly ordered composition [18]. Collagen type I, collagen type III, decorin, tenascin-C are fundamental proteins in the extracellular matrix of tendons. High expression levels of collagen type I and decorin seem to be essential for cells to be suitable for TTE applications, as they play an important role in tissue formation $[19,20]$. Scleraxis and tenomodulin are commonly used as markers for tenogenic differentiation [21-23].

Tenascin-C and fibronectin are two glycoproteins of the extracellular matrix, which are essential for cell-cell and cell-matrix interactions [24]. Aggrecan and osteopontin are located predominantly in the extracellular matrix of cartilage and bone.

The aim of this study was to examine if the LHB is suitable as cell source for TTE. Additionally, we compared two different isolation methods, ED and CM. In order to investigate the influence of these isolation methods on tenocyte-like cell cultures (TLCC), we analyzed cell morphology and gene expression. We hypothesized that both isolation methods deliver similar cell yield and show no differences in gene expression.

\section{Methods}

\section{Cell isolation procedure}

Tendon samples were obtained from patients, who underwent surgery for a primary shoulder arthroplasty. Surgery was performed by the senior author (P.E.M), an experienced shoulder surgeon. The study was carried out following the regulations of the Medical Center Ethics Committee of the Ludwig-Maximilians-University of Munich (ethical grant number: 063-09).

Altogether, seven tissue samples of the LHB were collected from patients with an average age of 60 years ( \pm 8.9 years). Tendon samples were carried to the laboratory in cell culture medium (DMEM/HAM's F12, Biochrom, Berlin, Germany) where cell isolation was immediately performed. Under sterile conditions tendons were washed three times with PBS buffer (Biochrom, Berlin, Germany) and cut into small pieces. For the following cell isolation previously published methods were used $[6,16,17]$. Briefly, the sheath and surrounding paratenon were removed and the tendons were minced into small pieces. At this stage, slices from each sample were randomly assigned to perform the following isolation procedure.

\section{ED method}

One part of the tendon slices was incubated in $0.2 \%$ collagenase I solution (Sigma-Aldrich, Steinheim, Germany) for approximately 18 hours in $37^{\circ} \mathrm{C}, \mathrm{CO}_{2} 5 \%$. After digestion, cells were filtered $(100 \mu \mathrm{m})$ (BD Biosciences, Erembodegem, Belgium), the suspension was washed three times with PBS buffer and centrifuged (Heraeus, Hanau, Germany) at $300 \mathrm{~g}$ for 5 minutes. Before cell cultivation, tenocytes were counted using a heamocytometer and trypan blue staining to distinguish between dead and vital cells.

\section{CM method}

The other part of the tendon slices were placed into petri-dishes filled with $10 \mathrm{ml}$ cell culture medium (DMEM/HAM's F12), supplemented with 10\% FCS, and were subcultivated $\left(37^{\circ} \mathrm{C}, \mathrm{CO}_{2} 5 \%\right)$. Culture medium was changed every second day. After a few days, the first colonies of migrating tenocytes around the slices could be seen. After approximately 3 weeks, the tendon slices were carefully transferred into new petri-dishes. Altogether three migration cycles were performed. Before cell cultivation the total number of cells was counted using a haemocytometer and trypan blue.

\section{Tendon cell cultures}

The isolated tenocytes were placed in culture flask in DMEM/HAM`s F12 (1:1) supplemented with 10\% FCS, $2 \mathrm{mM}$ L-Glutamin, ascorbic acid $1250 \mu \mathrm{g} / \mathrm{ml}$, amino acids, Penicillin/Streptomycin $60 \mu \mathrm{g} / \mathrm{ml}$ and Amphotericin B $25 \mathrm{ng} / \mathrm{ml}$ (Biochrom, Berlin, Germany). The seeding density for each isolation method was as follows: CM-714 cells $/ \mathrm{cm}^{2}$ and ED-2857 cells $/ \mathrm{cm}^{2}$. As soon as the cultured cells reached $80-90 \%$ confluence, they were 
treated with $0.05 \%$ trypsin $/ 0.02 \%$ ethylenediaminetetraaciticacid (EDTA) (Biochrom, Berlin, Germany) and subcultured. Osteoblasts (HOB lot: 540X130406) and fibroblasts (HFIB lot: $055 \mathrm{H} 170100)$ (Provitro, Berlin, Germany) were subcultured in DMEM cell culture medium. Supplements were the same as for TLCCs but without Amphotericin B. Chondrocytes were obtained from patients, who underwent total knee replacement, as previously descibed by us [25]. Morphological cell assessment was performed using a phase-contrast microscope (Zeiss, Munich, Germany). Total cell number was calculated after every cell passage.

\section{RT-PCR}

Tenocytes in the third passage were homogenized with lysis buffer (Quiagen, Hilden, Germany) using a QIAshredder (Quiagen) and a centrifuge at $8000 \mathrm{~g}$ for $3 \mathrm{~min}$ utes. For further purification of RNA, the RNeasy Mini Kit (Quiagen) was used following the manufacturer's manual. Leftovers of DNA were digested on-column with RNAse-free DNase I Set (Quiagen) for 15 minutes. cDNA was synthesized by using Reverse Transcription System Set (Promega, Mannheim, Germany) following the manufacturer's instruction. Briefly, $1 \mu \mathrm{g}$ of RNA, $4 \mu \mathrm{l}$ of $\mathrm{MgCl}_{2}, 2 \mu \mathrm{l}$ of $10 \mathrm{x}$ Reactionbuffer, $2 \mu \mathrm{l} 10 \mathrm{mM}$ Deoxynucleotidetriphosphate (dNTP)-mix, $0.5 \mu \mathrm{l}$ of RNase-inhibitor, $0.6 \mu \mathrm{l}$ Reverse Transcriptase, $0.5 \mu \mathrm{l}$ Randomprimer and RNase-free water were mixed up to a final volume of $20 \mu \mathrm{l}$. Samples were incubated for 10 minutes at $25^{\circ} \mathrm{C}$, following incubation at $42^{\circ} \mathrm{C}$ for 60 minutes. cDNA samples were stored at $-20^{\circ} \mathrm{C}$ until further use.

RT-PCR was performed for collagen type I, decorin, collagen type III, tenascin-C, fibronectin, Scleraxis, tenomodulin, osteopontin and aggrecan. Sequences and product lengths are shown in Table $1[17,26,27]$. For the RT-PCR, $1 \mu \mathrm{l}$ of cDNA was mixed with $0,5 \mu \mathrm{l}$ of forward and reverse primers (each $0.5 \mu \mathrm{M}$ ), 10x PCR buffer (100 mM Tris- $\mathrm{HCl}, \mathrm{pH} 8.8$ at $25^{\circ} \mathrm{C}, 500 \mathrm{mM} \mathrm{KCl}, 0.8 \%$ [v/v] Nonidet P40), 0,2 $\mu \mathrm{l}$ of Deoxynucleotidetriphosphate (dNTP)-mix (each $2 \mathrm{mM}), 1 \mu \mathrm{MgCl}_{2}(25 \mathrm{mM})$, $0,1 \mu \mathrm{l}$ of taq-polymerase $(5 \mathrm{u} / \mu \mathrm{l})$ (Fermentas, St. LeonRot, Germany) and filled up to a final volume of $20 \mu \mathrm{l}$ with RNase free water. The reaction mixtures were incubated for $3 \mathrm{~min}$ at $95^{\circ} \mathrm{C}$, followed by $30 \mathrm{sec}$ at $95^{\circ} \mathrm{C}$, $45 \mathrm{sec}$ at $50-64^{\circ}$ and $1 \mathrm{~min}$ at $72^{\circ} \mathrm{C}$ up to 35 cycles, and then $10 \mathrm{~min}$ at $72^{\circ} \mathrm{C}$. Products were analyzed by $2 \%$ gelelectrophoresis. To control results, at least two independent experiments were performed for all seven samples.

\section{qRT-PCR}

The gene expression of collagen type I alpha I and decorin was also determined by quantitative RT-PCR (qRT-PCR) using a light cycler instrument 2.0 (Roche Diagnostic, Mannheim, Germany). Target sequences were amplified using LightCycler Primer Sets (Search LC, Heidelberg, Germany) with LightCycler-Fast Start DNA Master SYBR Green I Mix (Roche Applied Science, Mannheim,

Table 1 RT-PCR primer sequences and product length

\begin{tabular}{|c|c|c|}
\hline Target gene & Primer sequence & Length \\
\hline \multirow[t]{2}{*}{ 1. GAPDH [NM_002046] } & Sense: GAGTCCACTGGCGTCTCCAC & $188 \mathrm{bp}$ \\
\hline & Antisense: GGTGCTAAGCAGTTGGTGGT & \\
\hline \multirow[t]{2}{*}{ 2. collagen Typ I, alpha 1 [NM_000088] } & Sense: GGCCCAGAAGAACTGGTACA & $200 \mathrm{bp}$ \\
\hline & Antisense: GGCTGTTCTTGCAGTGGTAG & \\
\hline \multirow[t]{2}{*}{ 3. collagen Typ III, alpha 1 [NM_033150] } & Sense: CCAGGAGCTAACGGTCTCAG & $103 \mathrm{bp}$ \\
\hline & Antisense. CAGGGTITCCATCTCTTCCA & \\
\hline \multirow[t]{2}{*}{ 4. decorin [NM_001920] } & Sense: TGCTGTTGACAATGGCTCTC & $192 \mathrm{bp}$ \\
\hline & Antisense: GCCTITTGGTGTTGTGTCC & \\
\hline \multirow[t]{2}{*}{ 5. fibronectin [NM_212475] } & Sense: ATGATGAGGTGCACGTGTGT & $135 \mathrm{bp}$ \\
\hline & Antisense: CTCTTCATGACGCTTGTGGA & \\
\hline \multirow[t]{2}{*}{ 6. tenascin-C [NM_002160] } & Sense: TCAAGGCTGCTACGCCTTAT & $230 \mathrm{bp}$ \\
\hline & Antisense: GTTCTGGGCTGCCTCTACTG & \\
\hline \multirow[t]{2}{*}{ 7. Scleraxis [17] } & Sense: CCTGAACATCTGGGAAATTTTAC & $111 \mathrm{bp}$ \\
\hline & Antisense: CGCCAAGGCACCTCCTT & \\
\hline \multirow[t]{2}{*}{ 8. tenomodulin [NM_022144] } & Sense: CCATGCTGGATGAGAGAGGT & $123 \mathrm{bp}$ \\
\hline & Antisense: CTCGTCCTCCTTGGTAGCAG & \\
\hline \multirow[t]{2}{*}{ 9. osteopontin [26] } & Sense: TTGCTITGCCTCCTAGGCA & $430 \mathrm{bp}$ \\
\hline & Antisense: GTGAAAACTTCGGTTGCTGG & \\
\hline \multirow[t]{2}{*}{ 10. aggrecan [27] } & Sense: CACTGTTACCGCCACTTCCC & $183 \mathrm{bp}$ \\
\hline & Antisense: ACCAGCGGAAGTCCCCTTCG & \\
\hline
\end{tabular}


Germany) following the manufacture's manual. Reactions were performed in doublets. At least two independent experiments were performed for all seven samples and difference in efficiency had to be less than 0.05 . For relative quantification of the gene expression, samples were normalized to cyclophilin B. Primer sequences are property of Search LC, Heidelberg, Germany and cannot be mentioned in this paper. (Lot numbers: Cyclophilin B: 120906, 090408, collagen type I alpha 1: 290606, 020608, dcorin: 140508).

\section{Statistics}

Data is shown as mean \pm SD. Statistical analysis was performed using GraphPad Prism 3.0 (San Diego CA, USA). The Mann-Whitney test was used to analyze significant differences between the groups (ED and CM). For comparison of multiple time points in one group, the Friedman test for multivariate analysis and Dunn's multiple comparison tests were used. Both tests are designed for paired samples. Level of significance was set up p $<0.05$.

\section{Results}

\section{Cell yield was significantly higher with enzymatic} digestion (ED) method

For cell isolation using CM, $0.11 \mathrm{~g} \pm 0.09 \mathrm{~g}$ of the LHB was used. Respectively, for isolation using ED $0.337 \mathrm{~g} \pm$ $0.19 \mathrm{~g}$ of tendon tissue was used. As we expected a higher loss of cells due to enzymatic treatment we used three times more tissue for ED compared to CM. After seven weeks, an average of $75 \times 10^{3}$ cells could be generated using $\mathrm{CM}$. Using ED as isolation method an average of $3.15 \times 10^{6}$ cells could be isolated with approximately 17 hours. In relation to $1 \mathrm{~g}$ of the LHB, CM could generate $6.70 \times 10^{5}$ cells while ED could generate $9.35 \times 10^{6}$ cells, meaning a ratio $1: 14$ (CM:ED). An overview over time and cell yield gives Figure 1.

\section{Cell morphology was similar for both isolation methods}

First migrating cells could be seen around the tendon slices after one week. With increasing culture time these colonies became denser and reached a confluence of about $90 \%$ after three weeks. Accelerated cell migration could be observed during the following cell migration cycles (Figure 2).

Figure 3 shows TLCCs of the second and third passage. Cell morphology was similar for both groups investigated. Even in the fourth passage, cells exhibited elongated shapes and several membrane protrusions. Over time, however, the amount of polygonal-shaped cells increased in both groups. Overall, the number of cells significantly increased from passage 1 to $3(\mathrm{p}<0.001)$ in both groups. However yield of cell and proliferation seemed to be more variable for ED. (Figure 4).

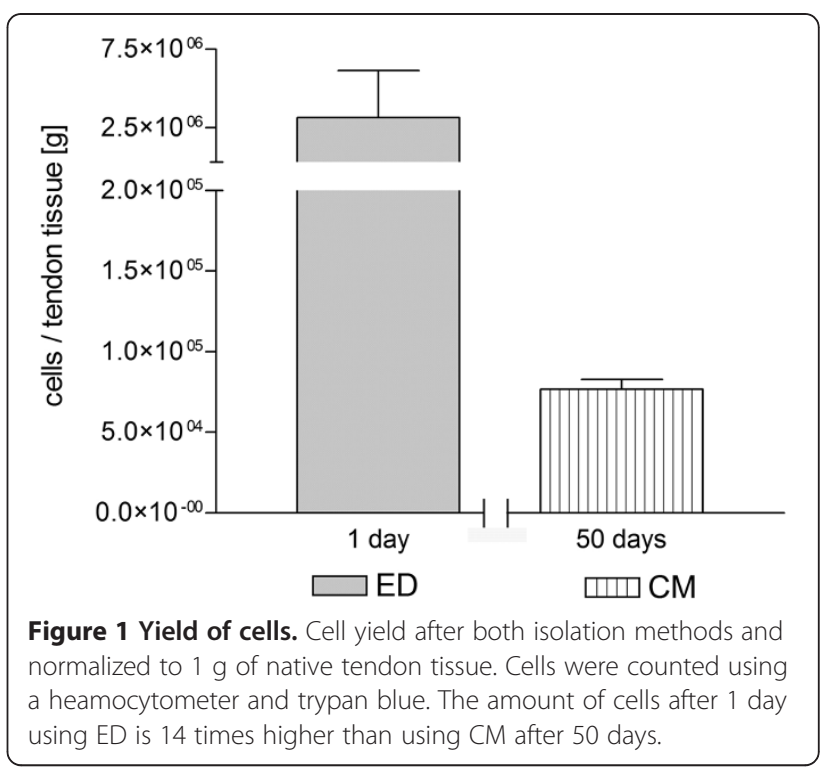

\section{Gene expression analysis showed comparable results in} both groups

To explore differences between the two isolation methods, the expression of main compounds of the extracellular matrix and tenogenic differentiation markers (Scleraxis and tenomodulin) were analyzed using RT-PCR. Results are shown in Figure 5.

The expression of collagen type I alpha I, collagen type III and decorin could be detected in TLCCs of both isolation methods. Cells of other musculoskeletal tissues also showed positive results on these three genes (line 2-4).

The expression of tenascin- $\mathrm{C}$ and fibronectin could be seen in all TLCC (line 5-6). The expression of Scleraxis was detected in all TLCC, too (line 7). Interestingly fibroblasts, chondrocytes and osteoblasts also showed Scleraxis expression. The expression of tenomodulin, could not be detected in any TLCC. Here, tenomodulin expression could be detected in chondrocytes and osteoblasts (line 8). Osteopontin was not expressed in TLCC (line 9), but could be seen in osteoblast cultures. Interestingly, the expression of aggrecan, could be observed in all TLCCs. Its expression was also seen in chondrocytes (line 10).

\section{qRT-PCR of collagen type I alpha I and decorin showed different expression in both groups}

Our results showed that the expression of collagen type I alpha I was higher in TLCC using ED as isolation method $(\leq 0.05)$. In contrast, decorin showed higher expression in TLCC using CM as isolation method $(\leq 0.05)$ (Figure 6). Collagen type I expression and decorin expression was about the same level in TLCC isolated by ED. If TLCCs were gained using CM, decorin expression was about five times higher than collagen type I expression. 

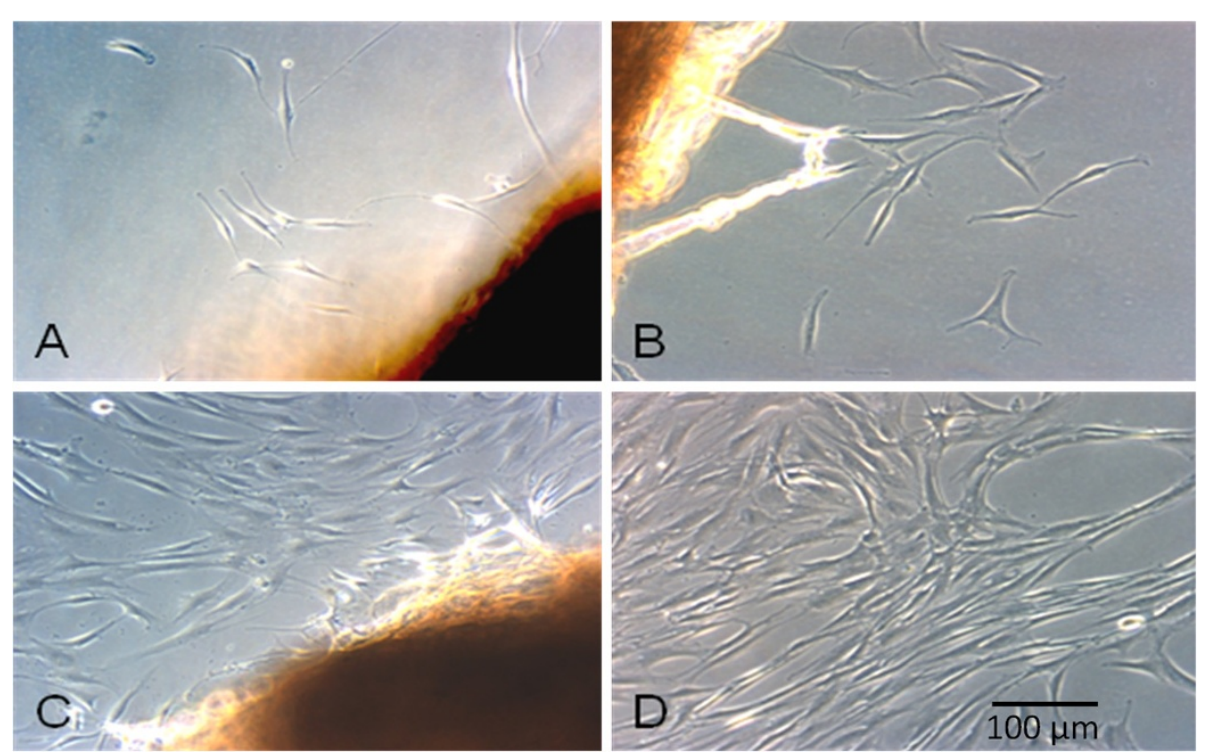

Figure 2 Migrating tenocytes of the LHB. The tendon slices were put into petri-dishes, incubated $\left(37^{\circ} \mathrm{C}, 5 \% \mathrm{CO}\right)$ in cell culture medium (DMEM/HAM's F12) and analyzed by light microscopy. An increasing amount of spindle-like cells could be observed at different time points. $\mathbf{A}=$ after 8 days, $\mathbf{B}=$ after 11 days, $\mathbf{C}=$ after 16 days $\mathbf{D}=$ after 22 days.

\section{Discussion}

It is important that TTE procedures, which aim to replace damaged tissue, only cause as little donor side morbidity as possible. The use of the LHB in TTE might be promising. It is removed regularly during shoulder operation as it often causes inflammation and pain. The loss of function is still under debate but in most cases the removal of this tendon is well tolerated by the patients [12-15,28].

Two different isolation methods can be used in TTE (ED and $C M)$. The aim of this study was to compare

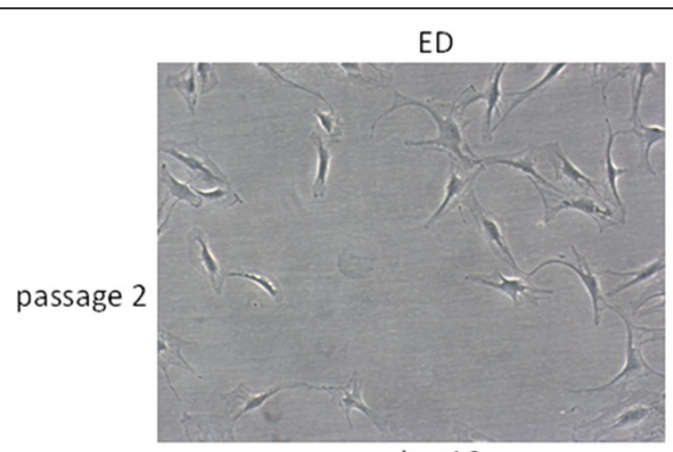

day 16

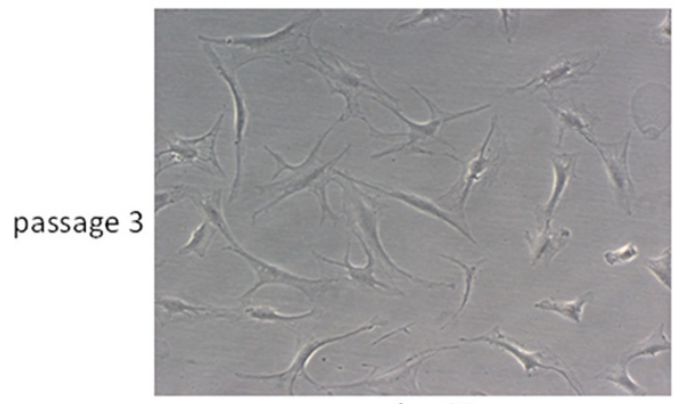

day 32

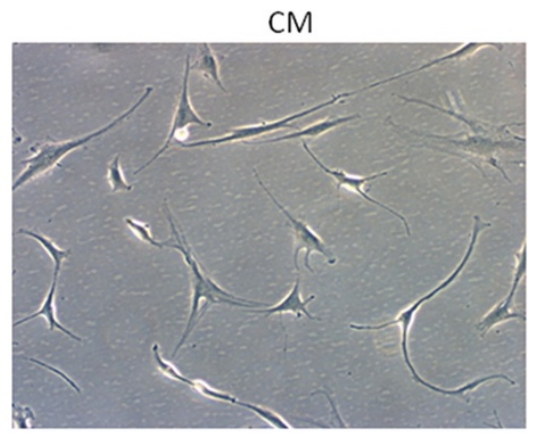

day 52

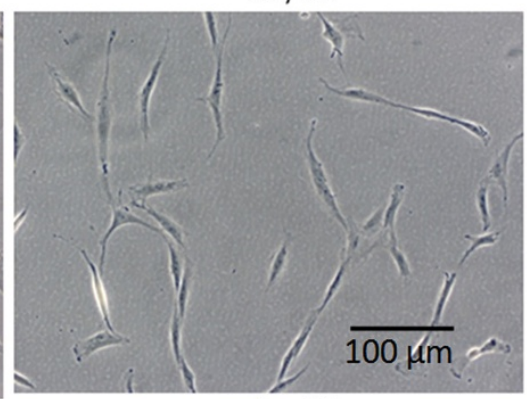

day 75

Figure 3 Cell morphology in TLCC. Tenocyte cell cultures at different time of subcultering. ED (enzymatic digestion) CM (cell migration). Cells of the second and third cell passage are shown. Cells show typical morpholpgy for tenocytes and no differences between both methods. 


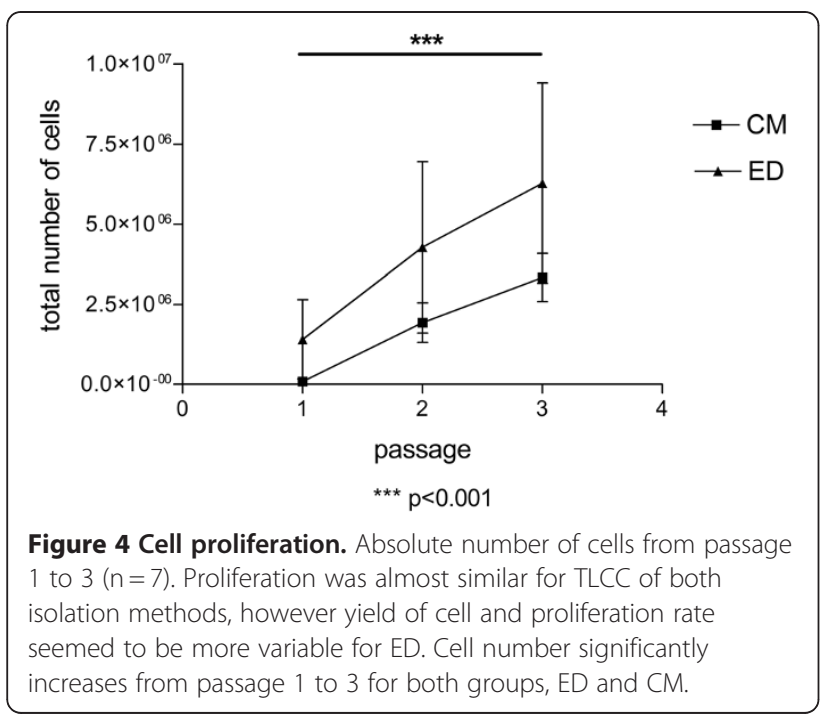

these two methods with regards to the quality of generated TLCCs. ED uses the enzyme collagenase I to separate cells from their extracellular matrix. The period of time to obtain cells is quite short (17 hours). Another advantage of this method is a higher cell yield compared to CM. This makes the method suitable for clinical use. $\mathrm{CM}$ is an alternative to isolate tenocytes from the LHB. A clear disadvantage of this method is that cell yield is poor and takes remarkably longer than

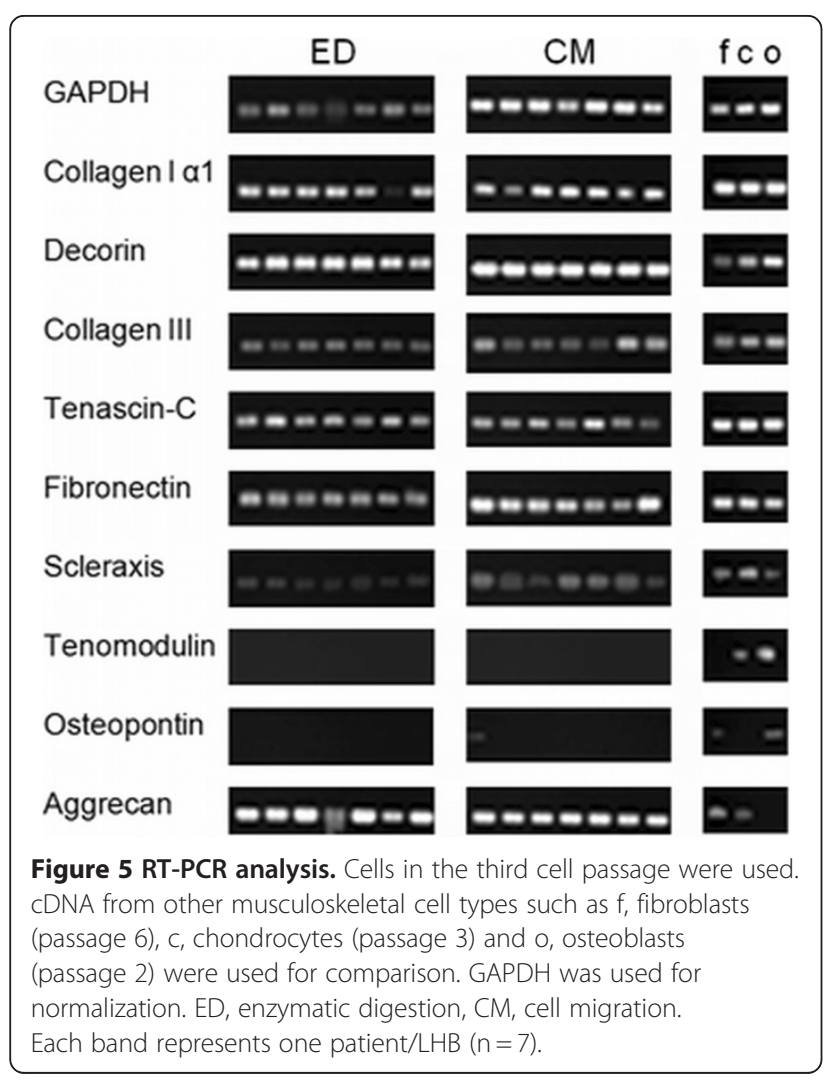

using ED (1-2 weeks) [17]. In our study, a reasonable number of cells could be obtained only after three migration cycles which lasted 6-8 weeks altogether. Our results showed that in relation to $1 \mathrm{~g}$ of native tissue ED could generate 14 times more cells than CM. Since, cell yield and the isolation time are essential for clinical use, this isolation method will not be clinically appropriate in nearer future.

It has been shown that tendons contain cells different from tenocytes. These cells are named tendon stem and progenitor cells (TSPC) [29-31]. We assumed that ED leads to obtaining both, tenocytes and TSPC, whereas cell migration tends to favor mature tenocytes. Therefore, we think that this might be an explanation for higher total number of cells in TLCCs isolated using ED throughout the passages as well as for higher variability of cell proliferation.

Cell morphology seemed to be similar in TLCCs no matter which isolation method was used. TLCCs of both isolation methods showed a significant increase in total cell number during passaging, illustrating a comparable cell-viability and -function.

All important structural compounds of the extracellular matrix in tendon such as collagen type I, collagen type III, decorin, tenascin-C and fibronectin were expressed continuously by all TLCC of the third cell passage. No difference could be detected between the two different isolation methods. Importantly, the transcription factor Scleraxis was expressed by all TLCC. It has been shown to play an important role in coordinating the response to injury in the pathogenesis of tendon disorders [32]. In contrast, tenomodulin expression could not be detected in TLCCs demonstrating a loss of this marker during passaging. This is in line with other studies by Yao, L. et al. [33] and Jelinsky et al. [34], which also showed a loss of tenomodulin expression in twodimensional culture systems.

The detection of aggrecan could be evidence for chondrogenic differentiation in TLCC [35]. In this study, we observed aggrecan expression in TLCC of both isolation methods. Former research could show that the use of collagenase type I has a negative effect on the differentiation of tenocytes. Lui, P. et al. could show, that the injection of collagenase $I$ in the patellar tendon leads to ectopic ossifications and to a chondrogenic gene expression profile [36]. This might also explain the expression of aggrecan in TLCC in this study, as the same enzyme was used for ED. As this enzyme was not used for CM isolation method we assume that aggrecan expression in these cultures might give evidence for a chondrogenic drift during cell culturing. High expression of aggrecan has been shown in degenerative tendons, which we used as a cell source. This could also be an explanation for our findings [37,38]. However, investigating aggrecan 

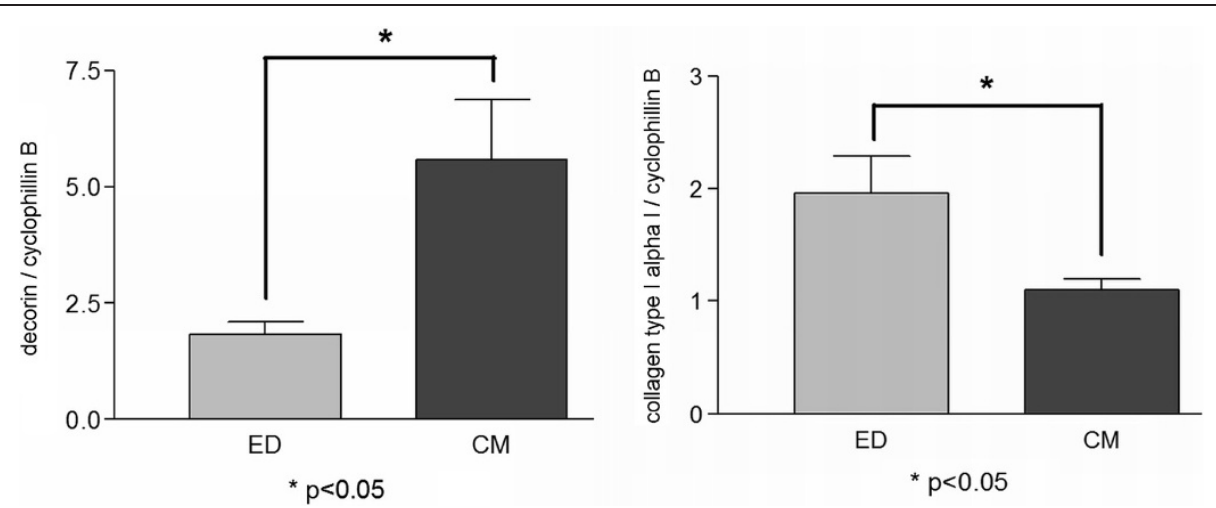

Figure 6 Quantitative RT-PCR. RT-PCR was performed for collagen type I and decorin. Relative gene expression was estimated against cyclophilin B.

expression in at least two separate cell passages is necessary for clarification. The osteogenic marker osteopontin could not be detected in any TLCC, no matter which isolation method was used. Osteogenic differentiation seemed unlikely.

Collagen type I and decorin are both essential proteins in the tendon tissue $[19,20]$, therefore we analyzed their expression levels by quantitative PCR. Our results showed that collagen type I expression was higher in TLCCs using ED. An influence on collagen type I expression by external applications, such as laser irradiation and shock waves was shown by Chen, $\mathrm{C}$. $\mathrm{H}$. et al. and Bosch, G. et al. [39,40]. Therefore, we assume that the use of collagenase type I, another external application, during cell isolation might up-regulate collagen type I expression. An increased expression of decorin could be seen in TLCC using CM. Findings of Karousou, E. et al. and Corps, A. N. et al. [37,41] indicate that decorin is up-regulated after tendon rupture. These findings were confirmed by Yokota et al., as they showed that the decorin expression in ruptured supraspinatues tendons is upregulated, too. This effect even aggravates during cell cultivation [38]. During the isolation process an artificial tendon rupture was generated. This might explain the higher expression of decorin in TLCCs isolated using CM. Ratio of mature tenocytes and TSPC might differ using different isolation methods and could generally be a possible explanation for the differences in collagen I/decorin expression.

\section{Conclusion}

In summary, it is possible to isolate cells from the LHB using both isolation methods (ED and $\mathrm{CM}$ ). Since no obvious disadvantage could be seen in morphological cell assesment of cells isolated by ED, this method seems to be more suitable for clinical use. The fact, that the intervening period between tendon explantation and cell seeding is remarkably shorter using ED compared to
$\mathrm{CM}$, increasing its clinical suitability. In addition to that, the high cell yield and collagen type I expression is another advantage of the ED isolation method. However, both methods need further optimization.

\section{Abbreviations}

CM: Cell migration; ED: Ezymatic digestion; LHB: Long head of the biceps tendon; TSPC: Tendon stem and progenitor cells; TLCC: Tenocyte-like cell culture; TTE: Tendon tissue engineering.

\section{Competing interests}

The authors declare that they have no competing interests.

\section{Authors' contributions}

MW and MP carried out the molecular experiments and drafted the manuscript. BS and DD helped with the establishment of RT-PCR and participated in the design of the study. MS conceived of the study and helped with the study design. PM and VJ participated in the coordination and helped to draft the manuscript. All authors have read the manuscript.

\section{Acknowledgements}

This study was supported by the "German Shoulder and Elbow Society" with 10.000€. Denitsa Docheva and Matthias Schieker were supported by the German Research Foundation (DFG grant DO 1414/1-1) and the Bavarian Research Foundation (FORZEBRA, TP1/WP2).

\section{Author details}

'Department of Orthopaedic Surgery, Ludwig-Maximilians-University Munich Campus Grosshadern, Marchioninistr 15, 81377, Munich, Germany. ${ }^{2}$ Experimental Surgery and Regenerative Medicine, Department of Surgery, Ludwig-Maximilians-University - Campus Innenstadt, Nußbaumstr 20, 80336, Munich, Germany.

Received: 6 November 2011 Accepted: 5 July 2012

Published: 8 August 2012

\section{References}

1. Clayton RA, Court-Brown CM: The epidemiology of musculoskeletal tendinous and ligamentous injuries. Injury 2008, 39:1338-1344.

2. Nevasier JS, Nevasier RJ, Nevasier TJ: The repair of chronic massive rotator cuff of the shoulder by use of a freeze-dried rotator cuff. J Bone Joint Surg Am 1978, 60:681-684.

3. Moore DR, Cain EL, Schwartz ML, Clancy WG Jr: Allograft reconstruction for massive, irreparable rotator cuff tears. Am J Sports Med 2006, 34:392-396.

4. Huang D, Balian G, Chhabra AB: Tendon tissue engineering and gene transfer: the future of surgical treatment. J Hand Surg [Am] 2006, 31:693-704 
5. Ouyang HW, Goh JC, Thambyah A, Teoh SH, Lee EH: Knitted poly-lactideco-glycolide scaffold loaded with bone marrow stromal cells in repair and regeneration of rabbit Achilles tendon. Tissue Eng 2003, 9:431-439.

6. Cao Y, Liu Y, Liu W, Shan Q, Buonocore SD, Cui L: Bridging tendon defects using autologous tenocyte engineered tendon in a hen model. PlastReconstrSurg 2002, 110:1280-1289.

7. Liu W, Chen B, Deng D, Xu F, Cui L, Cao Y: Repair of tendon defect with dermal fibroblast engineered tendon in a porcine model. Tissue Eng 2006 12:775-788

8. Bernard-Beaubois K, Hecquet C, Houcine O, Hayem G, Adolphe M: Culture and characterization of juvenile rabbit tenocytes. Cell Biol Toxicol 1997, 13:103-113.

9. Kryger GS, Chong AK, Costa M, Pham H, Bates SJ, Chang J: A comparison of tenocytes and mesenchymal stem cells for use in flexor tendon tissue engineering. J Hand Surg Am 2007, 32:597-605.

10. Berlemann $U$, Bayley I: Tenodesis of the long head of biceps brachii in the painful shoulder: improving results in the long term. J Shoulder Elbow Surg 1995, 4:429-435.

11. Murthi AM, Vosburgh CL, Neviaser TJ: The incidence of pathologic changes of the long head of the biceps tendon. J Shoulder Elbow Surg 2000, 9:382-385.

12. Kelly AM, Drakos MC, Fealy S, Taylor SA, O'Brien SJ: Arthroscopic release of the long head of the biceps tendon: functional outcome and clinical results. Am J Sports Med 2005, 33:208-213.

13. Gill TJ, Mclrvin E, Mair SD, Hawkins RJ: Results of biceps tenotomy for treatment of pathology of the long head of the biceps brachii. J Shoulder Elbow Surg 2001, 10:247-249.

14. Klepps S, Hazrati Y, Flatow E: Arthroscopic biceps tenodesis. Arthroscopy 2002, 18:1040-1045

15. Walch G, Edwards TB, Boulahia A, Nove-Josserand L, Neyton L, Szabo I: Arthroscopic tenotomy of the long head of the biceps in the treatment of rotator cuff tears: clinical and radiographic results of 307 cases. J Shoulder Elbow Surg 2005, 14:238-246.

16. Cao D, Liu W, Wei $X, X u F$, Cui $L$, Cao $Y$ : In vitro tendon engineering with avian tenocytes and polyglycolic acids: a preliminary report. Tissue Eng 2006, 12:1369-1377.

17. Schulze-Tanzil G, Mobasheri A, Clegg PD, Sendzik J, John T, Shakibaei M: Cultivation of human tenocytes in high-density culture. Histochem Cell Biol 2004, 122:219-228

18. Silver FH, Freeman JW, Seehra GP: Collagen self-assembly and the development of tendon mechanical properties. J Biomech 2003, 36:1529-1553.

19. Zhang G, Ezura Y, Chervoneva I, Robinson PS, Beason DP, Carine ET, Soslowsky $\sqcup$, lozzo RV, Birk DE: Decorin regulates assembly of collagen fibrils and acquisition of biomechanical properties during tendon development. J Cell Biochem 2006, 98:1436-1449.

20. Chokalingam K, Juncosa-Melvin N, Hunter SA, Gooch C, Frede C, Florert J, Bradica G, Wenstrup R, Butler DL: Tensile stimulation of murine stem cellcollagen sponge constructs increases collagen type I gene expression and linear stiffness. Tissue Eng Part A 2009, 15:2561-2570.

21. Docheva $D$, Hunziker EB, Fassler $R$, Brandau $O$ : Tenomodulin is necessary for tenocyte proliferation and tendon maturation. MolCell Biol 2005, 25:699-705.

22. Shukunami C, Takimoto A, Oro M, Hiraki Y: Scleraxis positively regulates the expression of tenomodulin, a differentiation marker of tenocytes. DevBiol 2006, 298:234-247.

23. Docheva D, Padula D, Popov C, Weishaupt P, Pragert M, Miosge N, Hickel R, Bocker W, Clausen-Schaumann H, Schieker M: Establishment of immortalized periodontal ligament progenitor cell line and its behavioural analysis on smooth and rough titanium surface. Eur Cell Mater 2010, 19:228-241.

24. Martin D, Brown-Luedi M, Chiquet-Ehrismann R: Tenascin-C signaling through induction of 14-3-3 tau. J Cell Biol 2003, 160:171-175.

25. Mayer-Wagner S, Schiergens TS, Sievers B, Redeker Jl, Schmitt B, Buettner A, Jansson V, Muller PE: Scaffold-free 3D cellulose acetate membrane-based cultures form large cartilaginous constructs. J Tissue Eng Regen Med 2011 5(2):151-155.

26. Crosby AH, Edwards SJ, Murray JC, Dixon MJ: Genomic organization of the human osteopontin gene: exclusion of the locus from a causative role in the pathogenesis of dentinogenesis imperfecta type II. Genomics 1995 27:155-160
27. Gronthos S, Zannettino AC, Hay SJ, Shi S, Graves SE, Kortesidis A, Simmons PJ: Molecular and cellular characterisation of highly purified stromal stem cells derived from human bone marrow. J Cell Sci 2003, 116:1827-1835

28. Wolf RS, Zheng N, Weichel D: Long head biceps tenotomy versus tenodesis: a cadaveric biomechanical analysis. Arthroscopy 2005, 21:182-185

29. Bi Y, Ehirchiou D, Kilts TM, Inkson CA, Embree MC, Sonoyama W, Li L, Leet $\mathrm{Al}$, Seo BM, Zhang L, et al: Identification of tendon stem/progenitor cells and the role of the extracellular matrix in their niche. Nat Med 2007, 13:1219-1227.

30. Zhang J, Wang JH: Platelet-rich plasma releasate promotes differentiation of tendon stem cells into active tenocytes. Am J Sports Med 2010, 38:2477-2486

31. Zhu J, Li J, Wang B, Zhang WJ, Zhou G, Cao Y, Liu W: The regulation of phenotype of cultured tenocytes by microgrooved surface structure. Biomaterials 2010, 31:6952-6958.

32. Scott A, Sampaio A, Abraham T, Duronio C, Underhill TM: Scleraxis expression is coordinately regulated in a murine model of patellar tendon injury. J Orthop Res 2010, 29(2):289-296.

33. Yao L, Bestwick CS, Bestwick LA, Maffulli N, Aspden RM: Phenotypic drift in human tenocyte culture. Tissue Eng 2006, 12:1843-1849.

34. Jelinsky SA, Archambault J, Li L, Seeherman H: Tendon-selective genes identified from rat and human musculoskeletal tissues. J Orthop Res 2010, 28:289-297

35. de MM, Koevoet W, van Schie HT, Kops N, Jahr H, Verhaar JA, van Osch G: In vitro model to study chondrogenic differentiation in tendinopathy. AmJ Sports Med 2009, 37:1214-1222.

36. Lui PP, Fu SC, Chan LS, Hung LK, Chan KM: Chondrocyte phenotype and ectopic ossification in collagenase-induced tendon degeneration. J Histochem Cytochem 2009, 57:91-100.

37. Corps AN, Robinson AH, Movin T, Costa ML, Hazleman BL, Riley GP: Increased expression of aggrecan and biglycan mRNA in Achilles tendinopathy. Rheumatology(Oxford) 2006, 45:291-294.

38. Yokota A, Gimbel JA, Williams GR, Soslowsky LJ: Supraspinatus tendon composition remains altered long after tendon detachment. J Shoulder Elbow Surg 2005, 14:72S-78S

39. Chen $\mathrm{CH}$, Tsai JL, Wang $\mathrm{YH}$, Lee $\mathrm{CL}$, Chen JK, Huang MH: Low-level laser irradiation promotes cell proliferation and mRNA expression of type I collagen and decorin in porcine Achilles tendon fibroblasts in vitro. J OrthopRes 2009, 27:646-650.

40. Bosch $\mathrm{G}$, de MM, van BR, van Schie HT, van de Lest $\mathrm{CH}$, van Weeren PR: The effect of focused extracorporeal shock wave therapy on collagen matrix and gene expression in normal tendons and ligaments. Equine VetJ 2009, 41:335-341

41. Karousou E, Ronga M, Vigetti D, Passi A, Maffulli N: Collagens, proteoglycans, MMP-2, MMP-9 and TIMPs in human achilles tendon rupture. ClinOrthopRelat Res 2008, 466:1577-1582.

doi:10.1186/1471-2474-13-140

Cite this article as: Wagenhäuser et al:: Collagen type I and decorin expression in tenocytes depend on the cell isolation method. BMC Musculoskeletal Disorders 2012 13:140.

\section{Submit your next manuscript to BioMed Central and take full advantage of:}

- Convenient online submission

- Thorough peer review

- No space constraints or color figure charges

- Immediate publication on acceptance

- Inclusion in PubMed, CAS, Scopus and Google Scholar

- Research which is freely available for redistribution 